\title{
Feeding synthetic zeolite to transition dairy cows alters neutrophil gene expression
}

\author{
M. A. Crookenden, ${ }^{1,2 *}$ ๑ C. V. C. Phyn, ${ }^{1} \odot$ S. A. Turner, ${ }^{1,3} \odot$ J. J. Loor, ${ }^{4}{ }^{\oplus}$ A. I. Smith, ${ }^{1,5}$ V. Lopreiato, ${ }^{4,6}{ }^{\oplus}$ \\ C. R. Burke, ${ }^{1}$ (D) A. Heiser, ${ }^{2}$ (D) and J. R. Roche ${ }^{5}$ (D) \\ ${ }_{1}^{1}$ DairyNZ Ltd., Cnr Ruakura and Morrinsville Rds (SH26), Newstead, Hamilton 3284, New Zealand \\ ${ }^{2}$ AgResearch, Hopkirk Research Institute, Palmerston North 4472, New Zealand \\ ${ }^{3}$ Dairy Goat Co-operative, Melville, Hamilton 3206, New Zealand \\ ${ }^{4}$ Department of Animal Sciences, University of Illinois, Urbana 61801 \\ ${ }^{5}$ University of Auckland, Auckland, New Zealand 1010 \\ ${ }^{6}$ Department of Animal Sciences, Food and Nutrition, Università Cattolica del Sacro Cuore, 29122 Piacenza, Italy
}

\section{ABSTRACT}

Synthetic zeolites are used to control the availability of dietary minerals (e.g., $\mathrm{Ca}, \mathrm{Mg}$, and $\mathrm{P}$ ) in dairy cows. Due to calcium demand increasing with lactation onset, most cows become hypocalcemic immediately postpartum, which likely contributes to poorer immune function because calcium is important for immune cell signaling. To overcome postpartum hypocalcemia, we fed transition cows synthetic zeolite A (sodium aluminosilicate) precalving and hypothesized that it would alter calcium and thus neutrophil function during the transition period. Multiparous Holstein-Friesian cows in late gestation were randomly allocated to an untreated control group $(\mathrm{n}=10)$ or a treatment group in which each cow received $500 \mathrm{~g}$ of zeolite A daily ( $\mathrm{n}=$ 10) for $14 \mathrm{~d}$ prior to the expected calving date (actual duration $=17 \pm 3 \mathrm{~d}$ prepartum). The cows grazed pasture, and each was supplemented with $2 \mathrm{~kg} / \mathrm{d}$ of maize silage (dry matter basis), with or without zeolite, until calving. Blood samples for neutrophil isolation and analysis of plasma indicators of mineral status, energy status, liver function, and inflammation were collected pretreatment (covariate; $\mathrm{d}-19$ ); on $\mathrm{d}-14$ and -7 precalving; on the day of calving (d 0$)$; and on d 1, 4, 7, and 28 postcalving. Neutrophils were isolated and gene expression was analyzed using microfluidic gene expression arrays. Neutrophil respiratory burst was assessed using stimulation with phorbol 12-myristate 13 -acetate and flow cytometry. Plasma calcium and phosphorus revealed a treatment by time interaction; cows offered zeolite had greater plasma calcium concentrations at d 0,1 , and 4 postcalving and plasma phosphorus con-

Received June 11, 2019.

Accepted August 30, 2019.

*Corresponding author: mallory.crookenden@agresearch.co.nz centrations were lower in zeolite-treated cows during the precalving period until d 1 postcalving compared with control animals. Zeolite treatment downregulated neutrophil gene expression of CXCR4 and S100A8 and tended to lower gene expression for other immune mediators (CXCR1, IFNG, S100A12, and S100A9) compared with the control. Zeolite treatment did not affect neutrophil respiratory burst or expression of the other genes investigated. Plasma concentrations of cytokine IL-6 were reduced with zeolite treatment, which was most evident immediately postcalving (d 0,1 , and 7). Overall, feeding zeolite precalving had few effects on neutrophil gene expression and function; however, the lower gene expression of neutrophil inflammatory mediators may be due to altered availability of dietary minerals prepartum and indicates that zeolite A may control inflammation during the transition period.

Key words: hypocalcemia, minerals, transition period

\section{INTRODUCTION}

The transition period, defined as the 2 to 3 wk before and after parturition, encompasses the onset of lactation. Dairy cows are most at risk of metabolic and infectious disease such as mastitis, ketosis, retained placenta, fatty liver, and milk fever/clinical hypocalcemia during the transition period compared with any other time during the lactation cycle (Goff and Horst, 1997; Mulligan and Doherty, 2008). The increased susceptibility to disease is influenced by poorer immune function in both innate and adaptive immune responses during the period leading up to parturition and in the weeks afterward (Kehrli et al., 1989a,b; Heiser et al., 2015; Crookenden et al., 2016). The studies, conducted in both grazing dairy cows and housed animals offered a TMR diet, suggest that the underlying immunological changes during the transition period contribute to the various pathologies. 
Hypocalcemia is the most prevalent metabolic disorder at calving due to the sudden increased demand for calcium by the mammary gland for milk production. Clinical hypocalcemia (blood $\mathrm{Ca}<1.4 \mathrm{mmol} / \mathrm{L}$ ) occurs in approximately 3 to $10 \%$ of dairy cows (DeGaris and Lean, 2008; Goff, 2008; Mulligan and Doherty, 2008); however, this incidence varies between farms and farm systems (Horst et al., 2003; Roche, 2003). Subclinical hypocalcemia (blood $\mathrm{Ca}<2-2.15 \mathrm{mmol} / \mathrm{L}$ ) is more common than clinical hypocalcemia and contributes to the increased risk of other health disorders (Curtis et al., 1983, 1985; Reinhardt et al., 2011; Neves et al., 2018). An estimated 40 to $65 \%$ of dairy cows undergo a state of subclinical hypocalcemia at the onset of lactation, meaning that a large proportion of cows in a dairy herd are at risk of compromised animal health, welfare, and productivity (Roche, 2003; Reinhardt et al., 2011; Oetzel, 2013).

Calcium availability and its demand affect various cells of the immune system, which likely contributes to the increased risk of disease in hypocalcemic dairy cows. Calcium is an important messenger during immune cell activation and depends on intracellular stores and extracellular $\mathrm{Ca}^{2+}$ (Grafton and Thwaite, 2001; Vig and Kinet, 2009). Hypocalcemia has a detrimental effect on neutrophil respiratory burst in both peripartal cows with postcalving hypocalcemia and nonlactating cows with induced subclinical hypocalcemia (Martinez et al., 2012, 2014). Moreover, stimulated peripheral blood mononuclear cells demonstrate less intracellular calcium flux in cows with clinical hypocalcemia compared with cows with normocalcemia (Kimura et al., 2006).

Zeolites are microporous minerals commonly used as adsorbents in industry and agriculture due to their ability to bind cations and some anions (Mumpton, 1999). When added to the feed of cattle, synthetic zeolite A (sodium aluminosilicate) adsorbs dietary calcium during digestion, thereby making it unavailable for intestinal absorption and it passes out in the feces. It also binds dietary magnesium and phosphorus (Thilsing et al., 2006; Grabherr et al., 2009), key minerals involved in calcium homeostasis. These effects create a state of negative calcium balance, which is thought to activate calcium homeostatic mechanisms in a similar manner to feeding a calcium-deficient $(<20 \mathrm{~g} / \mathrm{d}$ of absorbable calcium) diet prepartum. This latter mechanism stimulates parathyroid hormone secretion, which increases the efficiency of intestinal absorption of calcium from the diet, reduces renal calcium excretion, and stimulates osteoclastic bone resorption (Goff, 2008). This prepares the cow for effective absorption of dietary calcium and rapid mobilization of bone calcium stores at the onset of lactation when zeolite is removed from the diet and calcium demand dramatically increases. The risk of clinical and subclinical hypocalcemia is reduced, with blood calcium concentrations remaining normocalcemic early postpartum in cows that received zeolite A for up to 4 wk prepartum (Thilsing-Hansen and Jørgensen, 2001; Thilsing et al., 2007; Kerwin et al., 2019). We hypothesize that prepartum zeolite treatment will improve neutrophil function due to its effects on key minerals involved in calcium homeostasis (e.g., calcium, magnesium, and phosphorus), leading to increased availability of blood calcium with the onset of lactation. Thus, we investigated gene expression and functional changes of neutrophils and associated changes in plasma indicators of energy status, liver function, minerals, and inflammation during the transition period in response to precalving feeding of zeolite A.

\section{MATERIALS AND METHODS}

\section{Animal Handling}

The Ruakura Animal Ethics Committee (Hamilton, New Zealand) approved all animal manipulations in accordance with the New Zealand Animal Welfare Act (Ministry for Primary Industries, 1999). The feeding experiment was undertaken at Lye Farm, Hamilton, New Zealand $\left(37^{\circ} 45^{\prime} \mathrm{S}, 175^{\circ} 21^{\prime} \mathrm{E}\right)$ between June 21 and August 16, 2016.

\section{Experimental Design and Treatments}

Precalving, all cows grazed fresh pasture ( $82 \%$ perennial ryegrass, Lolium perenne; $9 \%$ white clover, Trifolium repens; $3 \%$ weeds and other grasses; $6 \%$ dead material; $11 \mathrm{MJ}$ of $\mathrm{ME} / \mathrm{kg}$ of DM; $13 \% \mathrm{DM}$ ) in the same paddock with a common allowance to target pasture intakes of $9 \mathrm{~kg} \mathrm{DM} /$ cow per day. The cows were also individually supplemented once per day with $5 \mathrm{~kg}$ (wet weight) of maize silage (10 MJ of $\mathrm{ME} / \mathrm{kg}$ of $\mathrm{DM} ; 36 \% \mathrm{DM}$ ) in a covered concrete feeding facility in the mornings before a fresh allocation of pasture. Twenty late-gestation, parous cows of mixed age $(4.8 \pm 1.5 \mathrm{yr}$; average $\pm \mathrm{SD})$ and breed (Holstein-Friesian, $\mathrm{n}=18$; Holstein-Friesian $\times$ Jersey, $\mathrm{n}=2$ ) were randomly allocated to 1 of 2 treatment groups (control $\mathrm{n}=10$ or zeolite $\mathrm{n}=10$ ). The groups were assessed to ensure they were balanced for age, breed, BCS and live weight before enrollment, previous milk production, and expected calving date (range July 5-12, 2016). In the zeolite experimental treatment group, synthetic zeolite A (Optimate MF+, Blue Pacific Minerals, Tokoroa, New Zealand) was individually fed mixed into the maize silage $(500 \mathrm{~g} /$ cow per day; equivalent to $400 \mathrm{~g}$ of sodium aluminosilicate) to 10 cows for at least $14 \mathrm{~d}$ before their estimated calving 
date (actual duration of $17 \pm 3 \mathrm{~d}$ prepartum; mean \pm $\mathrm{SD}$ ), but for no longer than $21 \mathrm{~d}$. Zeolite feeding ceased at calving. Control cows $(\mathrm{n}=10)$ were offered the same diet (actual duration of $20 \pm 3$ d prepartum; mean \pm $\mathrm{SD})$, but without the addition of zeolite to the maize silage. Postcalving, all cows grazed together and were offered the same diet, grazed fresh pasture (allowance $>35 \mathrm{~kg} \mathrm{DM} /$ cow per day to ground level; $89 \%$ perennial ryegrass, L. perenne; $3 \%$ white clover, T. repens; $6 \%$ weeds and other grasses; $2 \%$ dead material; $11 \mathrm{MJ}$ $\mathrm{ME} / \mathrm{kg} \mathrm{DM} ; 16 \% \mathrm{DM}$ ) to target 1,500 to $1,600 \mathrm{~kg} \mathrm{DM} /$ ha per pasture break following a 24-h grazing period, supplemented with maize silage and pasture silage if insufficient pasture was available to meet grazing residual targets.

To replicate standard farm practice, cows were provided with magnesium supplementation from 2 to 3 wk precalving by dusting the pasture pregrazing with magnesium oxide [Causmag (Causmag International, Young, NSW, Australia); 55\% magnesium] at a dose of 80 to $100 \mathrm{~g} /$ cow per day. In addition, cows received 200 $\mathrm{g} /$ cow per day of calcium carbonate postcalving for $4 \mathrm{~d}$ during the colostrum period.

Cows had been fed to achieve a BCS of 5.0 [4.90 \pm 0.07 , average \pm standard error of the difference (SED); based on a 10-point scale; Roche et al., 2004] at the start of zeolite A feeding. Cows were milked twice daily and had an average FCM yield of $25.9 \pm 0.75 \mathrm{~kg} / \mathrm{d}$ $( \pm \mathrm{SED}), \mathrm{SCC}$ of $(25 \pm 0.09) \times 10^{3}$ cells $/ \mathrm{mL}( \pm \mathrm{SED})$, and average BCS of $4.2 \pm 0.1( \pm$ SED) over the first 12 wk of lactation; no difference $(P>0.05)$ was found between treatment groups for these parameters.

Blood was sampled by coccygeal venipuncture before the start of treatment (average of -19 d relative to actual calving date) and every subsequent $4 \mathrm{~d}$ to achieve sampling time points at $d-14$ and -7 (average of 15 and $9 \pm 1 \mathrm{~d}$ precalving $\pm \mathrm{SD}$, respectively) and post calving on the day of calving (d 0), d 1 , and $\mathrm{d} 4$, and approximately $( \pm 1 \mathrm{~d})$ on $\mathrm{d} 7$ and 28 , relative to calving. Blood for neutrophil isolation (total of $\sim 15 \mathrm{~mL}$ per cow at each time point) was collected into 2 evacuated blood tubes containing a lithium heparin anticoagulant (Vacutainer; BD Bioscience, Plymouth, UK). Blood tubes were inverted 8 to 10 times and placed immediately on ice awaiting neutrophil isolation by differential centrifugation using SepMate tubes (Stemcell Technologies, Tullamarine, VIC, Australia) with modifications described below. Blood for analysis of metabolites and inflammatory markers $(\sim 7 \mathrm{~mL})$ was also collected in evacuated blood tubes containing lithium heparin, inverted, and placed immediately on ice; within $30 \mathrm{~min}$, the tubes were centrifuged at $1,500 \times g$ for $12 \mathrm{~min}$ at $4^{\circ} \mathrm{C}$, the plasma was aspirated, and aliquots stored at $-20^{\circ} \mathrm{C}$ (metabolites) and $-80^{\circ} \mathrm{C}$ (inflammatory markers) until assayed.

\section{Plasma Analysis}

Plasma was analyzed for markers of mineral status, energy status, liver function, and inflammation. Details of laboratory analyses used are described elsewhere by Roche et al. (2015), and the methods are briefly described below.

Blood Metabolites. Indicators of mineral status, energy status, and liver function were analyzed by Gribbles Veterinary Pathology Ltd. (Hamilton, New Zealand) using colorimetric techniques at $37^{\circ} \mathrm{C}$ with a Hitachi Modular P800 analyzer (Roche Diagnostics, Indianapolis, IN). Roche reagent kits were used to measure plasma concentrations of calcium $(\mathrm{mmol} / \mathrm{L}$; 5-nitro-5'-methyl-(1,2-bis(o-aminophenoxy)ethan$N, N, N^{\prime}, N^{\prime}$-tetraacetic acid (NM-BAPTA) method; CA2 Kit), magnesium (mmol/L; xylidyl blue reaction; $\mathrm{Mg}$ Kit), bicarbonate (mmol/L; reactivity with phosphoenolpyruvate in the presence of phosphoenolpyruvate carboxylase method; CO2-L Kit), inorganic phosphorus $(\mathrm{mmol} / \mathrm{L}$; reactivity with ammonium molybdate to form ammonium phosphomolybdate without reduction in presence of sulfuric acid; PHOS Kit), albumin $(\mathrm{g} / \mathrm{L}$; bromocresol green reaction at $\mathrm{pH}$ 4.1; ALB plus Kit), $\mathrm{BHB}$ (mmol/L; reduction of $\mathrm{NAD}^{+}$to $\mathrm{NADH}$ during oxidation of d-3-hydroxybutyrate to acetoacetate; $\mathrm{BOH}$ Kit), and total protein (g/L; biuret method; TP Kit). Plasma globulin was calculated as the difference between total protein and albumin. Plasma nonesterified fatty acid (FA) concentrations (mmol/L) were measured using the acyl Co-A synthetase, acyl-CoA oxidase (ACS-ACOD) colorimetric method (NEFA C Kit; Wako Chemicals, Osaka, Japan). The inter- and intraassay coefficients of variation for assays were between 0.8 and $5.3 \%$ and between 0.5 and $15 \%$, respectively.

Inflammatory Markers. Markers of inflammation were analyzed at the University of Illinois (Champaign, IL). Interleukin-1 $\beta$ and IL-6 were analyzed using bovine ELISA kits (Pierce, Thermo Scientific, Rockford, IL, and GenWay Biotech Inc., San Diego, CA). A total of $100 \mu \mathrm{L}$ of undiluted sample was used to perform each assay and absorbance was read using a microplate spectrophotometer (Biotek Instruments, Winooski, VT).

Haptoglobin was measured by a bovine ELISA kit (Life Diagnostics Inc., West Chester, PA). Samples were diluted 1:2,000 with kit reagents. A total of 100 $\mu \mathrm{L}$ of diluted sample was used to perform the assay, and absorbance was read using a microplate spectrophotometer (Biotek Instruments, Winooski, VT). For

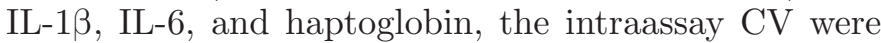


6,10 , and $5 \%$, respectively, and the interassay CV were 7,13 , and $7 \%$, respectively.

Plasma reactive oxygen species were assessed using a fluorimetric kit (Cell Biolabs, San Diego, CA), which uses dichlorodihydrofluorescin oxidization to fluorescent $2^{\prime}, 7^{\prime}$-dichlorodihydrofluorescein by reactive oxygen species. A total of $50 \mu \mathrm{L}$ of undiluted sample was used to perform the assay. Fluorescence was measured with a fluorometric microplate reader with an excitation wavelength of $480 \mathrm{~nm}$ and emission wavelength of 530 nm (Biotek Instruments).

The total antioxidant capacity of plasma was assayed using a colorimetric kit (Cayman Chemical Company, Ann Arbor, MI). Samples were diluted 1:20 with kit reagents. A total of $10 \mu \mathrm{L}$ of diluted sample was used and absorbance was read with a microplate spectrophotometer (Biotek Instruments). The intra- and interassay CV were 9 and $14 \%$, respectively.

Serum amyloid A was measured using an ELISA kit (Phase Range, Tridelta Development Ltd., Greystones, Co. Wicklow, Ireland) with a monoclonal antibody specific for serum amyloid A coated on the wells of the microplate strips provided by the company. Samples were diluted 1:400 with kit reagents. A total of $50 \mu \mathrm{L}$ of diluted sample was used with absorbance read at $450 \mathrm{~nm}$ using $630 \mathrm{~nm}$ as a reference, with a microplate spectrophotometer (Biotek Instruments). The intraand interassay CV were 3 and $5 \%$, respectively.

\section{Neutrophil Isolation}

Blood from each cow was diluted 1:1 with $1 \times$ PBS (pH 7.4) with $2 \%$ fetal bovine serum (In Vitro Technologies, Auckland, New Zealand) for neutrophil isolation. Diluted blood was carefully added to $50-\mathrm{mL}$ SepMate tubes (Stemcell Technologies) containing 15 $\mathrm{mL}$ of density gradient medium (Lymphoprep, $1.077 \mathrm{~g} /$ $\mathrm{mL}$; Stemcell Technologies). Tubes were centrifuged for $10 \mathrm{~min}$ at room temperature at 1,200 $\times g$ (with break on). After centrifugation, the top layer was discarded (mononuclear cell fraction), and tubes were centrifuged for an additional $10 \mathrm{~min}$ at room temperature at 1,200 $\times g$. The Lymphoprep was removed using a 16-gauge needle (BD Biosciences New Zealand, Mt. Wellington, Auckland) and 20-mL syringe (BD Biosciences) and discarded, and the remaining red blood cells and neutrophils were then collected $(\sim 5-10 \mathrm{~mL})$, yielding $80 \%$ neutrophils $\pm 2 \%$ (mean \pm SEM) and $99 \pm 0.1 \%$ live cells (mean \pm SEM) indicated by selecting neutrophil populations based on light angle scatter parameters using flow cytometry. Water (Milli-Q, Merck, Darmstadt, Germany) was added (25 mL) and mixed for 10 to $30 \mathrm{~s}$ to lyse the red blood cells, and $5 \mathrm{~mL}$ of 5 $\times$ concentrated PBS $(\mathrm{pH}$ 7.4, Life Technologies New Zealand Ltd., Auckland, New Zealand) was added to each tube to restore isotonicity. Tubes were centrifuged at $1,000 \times g$ for $10 \mathrm{~min}$ at $4^{\circ} \mathrm{C}$, and the supernatant was decanted to isolate the white cell pellet. The pellet was washed with $10 \mathrm{~mL}$ of $1 \times$ concentrated PBS $(\mathrm{pH}$ 7.4, Life Technologies), vortexed, and centrifuged for 5 min at $1,200 \times g$ at $4^{\circ} \mathrm{C}$. The water lysing step was repeated, and the resultant cell pellet was resuspended in $1.6 \mathrm{~mL}$ of $1 \times$ PBS $(\mathrm{pH} \mathrm{7.4)}$ ) and transferred to a $2-\mathrm{mL}$ microcentrifuge tube (Eppendorf, Hamburg, Germany). An aliquot of $100 \mu \mathrm{L}$ was pipetted into a flow cytometry tube (Falcon, In Vitro Technologies) and placed on ice for subsequent viability and respiratory burst assays. The remaining cells were centrifuged for $5 \mathrm{~min}$ at $1,000 \times g$ at room temperature. The supernatant was removed, and the cell pellet was resuspended in $1 \mathrm{~mL}$ of TRIzol reagent (Life Technologies New Zealand Ltd.) and stored at $-80^{\circ} \mathrm{C}$ for subsequent RNA extraction.

\section{Respiratory Burst Assay}

Neutrophil respiratory burst of each preparation was assessed using a neutrophil respiratory burst assay kit (601130, Sapphire Bioscience, New Zealand). Briefly, 2 aliquots of isolated neutrophils $\left(\sim 1 \times 10^{6}\right.$ cells $\left./ \mathrm{mL}\right)$ from all control animals were warmed $\left(37^{\circ} \mathrm{C}\right)$ in $100 \mu \mathrm{L}$ of assay buffer: RPMI 1640 cell culture medium (Life Technologies New Zealand Ltd.) supplemented with $10 \%$ fetal bovine serum of New Zealand origin (In Vitro Technologies) and $500 \mu \mathrm{L}$ of $1 \mathrm{M}$ calcium chloride. The dye, $10 \mu \mathrm{L}$ of dihydrorhodamine 123 at $5 \mu \mathrm{g} / \mathrm{mL}$, was added to both aliquots of cell suspension and incubated at $37^{\circ} \mathrm{C}$ for $15 \mathrm{~min}$. Phorbol 12 -myristate 13 -acetate was added to 1 aliquot of cell suspension at a final concentration of $200 \mathrm{nM}$ and incubated at $37^{\circ} \mathrm{C}$ for 45 min. After the incubation period, samples were centrifuged for $5 \mathrm{~min}$ at $500 \times \mathrm{g}$, the supernatant discarded, and the cells resuspended in $300 \mu \mathrm{L}$ of assay buffer and analyzed by flow cytometry for green fluorescence $(\sim 530 \mathrm{~nm})$ using a BD FACSVerse (BD Biosciences New Zealand). Neutrophil populations were selected based on forward angle light scatter and side scatter, and fluorescence of unstimulated cells was compared with that of cells stimulated with phorbol 12-myristate 13-acetate using FlowJo flow cytometry analysis software version 10.4.2 (FlowJo, LLC, Ashland, OR).

\section{Extraction of Ribonucleic Acid}

Total RNA was extracted from neutrophils using TRIzol reagent as per the manufacturer's instructions. Briefly, cell suspensions were homogenized in TRIzol 
using an Omni Tissue Homogenizer and Omni Hard Tissue Tip plastic probes (Omni International, Kennesaw, GA); suspensions underwent 3 short bursts of the homogenizer at full speed $(35,000 \mathrm{rpm})$. The homogenizer probe was replaced with a clean autoclaved probe between each sample and rinsed with RNaseZap (Life Technologies), 75\% molecular grade ethanol, and 3 times with UltraPure RNase/DNase-free distilled water (Life Technologies). Chloroform $(200 \mu \mathrm{L}$; 0.2 volume of TRIzol) was added to the homogenized samples, shaken for $15 \mathrm{~s}$, and left for $2 \mathrm{~min}$ at room temperature. Samples were centrifuged $\left(13,000 \times g\right.$ at $4^{\circ} \mathrm{C}$ for 15 $\mathrm{min}$ ), and the aqueous phase was carefully removed. Precipitation of RNA was achieved with the addition of isopropanol (Merck), and the subsequent RNA pellet was washed with $75 \%$ molecular grade ethanol, dried, and then resuspended in UltraPure RNase/DNase-free distilled water (Life Technologies). All RNA samples were DNase treated using the Ambion DNA-free kit (Life Technologies). The quantity of RNA was determined by spectrophotometry using a NanoPhotometer N60 (Implen GmbH, Munich, Germany), and RNA integrity was confirmed using a Fragment Analyzer (Advanced Analytical, Ankeny, IA) and Standard Sensitivity RNA Analysis Kit (Advanced Analytical). Samples had an average RNA integrity number of $9.0 \pm$ 0.93 (mean $\pm \mathrm{SD}$ ). Samples were stored at $-80^{\circ} \mathrm{C}$ until cDNA synthesis.

\section{Synthesis of Complementary DNA and Primer Design}

Total RNA $(1 \mu \mathrm{g})$ from each sample was reverse transcribed using a SuperScript III First-Strand Synthesis SuperMix for reverse-transcription quantitative PCR (RT-qPCR; Life Technologies New Zealand Ltd.). Reverse-transcriptase negative controls were also generated by excluding the enzyme (SuperScript III), and cDNA samples were stored at $-20^{\circ} \mathrm{C}$.

Assays for 24 gene targets (21 genes involved in neutrophil function and 3 endogenous control genes, selected based on current literature, Table 1) for use in RT-qPCR were designed using publicly available bovine gene sequences from the National Center for Biotechnology Information (NCBI) gene database (http:/ /www.ncbi.nlm.nih.gov). Assays were designed to span an intron-exon boundary, as possible, using Roche Universal Probe Library (UPL) design software. Primer sequences were verified by BLAST and PrimerBLAST analysis (NCBI) to ensure specificity. Assays were tested on a LightCycler 480 instrument (Roche, Basel, Switzerland). Each RT-qPCR amplification contained custom designed forward and reverse primers (200 nM,
IDT, Singapore), UPL unique probe (50 n $M$, Roche), LightCycler 480 Probes Master $(2 \times$ concentration $), 4$ $\mu \mathrm{L}$ of diluted $\mathrm{cDNA}$, and RNase/DNase-free distilled water. Standard cycling conditions were used $\left(95^{\circ} \mathrm{C}\right.$ for $10 \mathrm{~min} ; 40$ cycles of $95^{\circ} \mathrm{C}$ for $10 \mathrm{~s} 60^{\circ} \mathrm{C}$ for $30 \mathrm{~s}$; and $40^{\circ} \mathrm{C}$ for $40 \mathrm{~s}$ ). To test assays, a 6 -point 10 -fold standard curve was generated starting at $1 \times$ dilution (1:4 dilution of raw cDNA) to $1 \times 10^{-6}$ dilution. Positive and negative samples were verified with gel electrophoresis to ensure a single product free of genomic DNA contamination and to verify the amplicon size.

\section{Gene Expression}

Expression of genes by RT-qPCR was achieved using the BioMark HD real-time PCR system (Ramaciotti Centre for Genomics, Sydney, NSW, Australia). A microfluidics 192.24 Dynamic Array (Fluidigm, San Francisco, CA) integrated fluidic circuit chip combined with Roche UPL chemistry was used to generate expression results for 24 gene targets for all samples (n $=226)$. A pre-amplification of cDNA was undertaken to create specific target amplified reactions by multiplexing forward and reverse primers $(200 \mathrm{n} M)$ of the 96 assays with $5 \times$ concentration PreAmp Master Mix (Fluidigm) and the cycling protocol: $95^{\circ} \mathrm{C}$ for $10 \mathrm{~min}$ and 14 cycles of $95^{\circ} \mathrm{C}$ for $15 \mathrm{~s}$ and $60^{\circ} \mathrm{C}$ for $4 \mathrm{~min}$. Assay mixtures, including custom forward and reverse primers $(800 \mathrm{n} M)$, Roche UPL probes $(100 \mathrm{n} M)$, and 2 $\times$ concentration assay loading reagent (Fluidigm) were combined with $2 \times$ concentration Roche LightCycler 480 Probes Master (Roche) and $20 \times$ gene expression sample loading reagent (Fluidigm) on a 192.24 gene expression chip (Fluidigm) for use in the BioMark HD instrument. The gene expression cycling protocol "GE $96 \times 96$ UPL v1.pcl" (BioMark HD Data Collection software v3.0.2) was used to generate crossing point (Cp) values: $70^{\circ} \mathrm{C}$ for $30 \mathrm{~min}, 25^{\circ} \mathrm{C}$ for $10 \mathrm{~min}$, and $95^{\circ} \mathrm{C}$ for $1 \mathrm{~min}$, followed by 35 cycles of $96^{\circ} \mathrm{C}$ for $5 \mathrm{~s}$ and $60^{\circ} \mathrm{C}$ for $20 \mathrm{~s}$.

Three endogenous control genes (RPL13A, RPL19, and $Y W H A Z$ ) were selected for normalization based on previous gene expression research in neutrophils (Crookenden et al., 2017). Relative quantification was achieved using the delta $\mathrm{Cp}$ method: the geometric mean of the $\mathrm{Cp}$ values of the 3 endogenous control genes was calculated, and the target assay $\mathrm{Cp}$ values were made relative to the geometric mean of endogenous controls $(\Delta \mathrm{Cp})$. The fold change relative to the control group ( $\Delta \Delta \mathrm{Cp}$; Table 2$)$ can be calculated as shown in Equation [1]:

$$
\Delta \Delta \mathrm{Cp}=2^{-(\Delta \mathrm{Cp} \text { zeolite }-\Delta \mathrm{Cp} \text { control }) .}
$$


Crookenden et al.: ZEOLITE AAND PMN GENE EXPRESSION

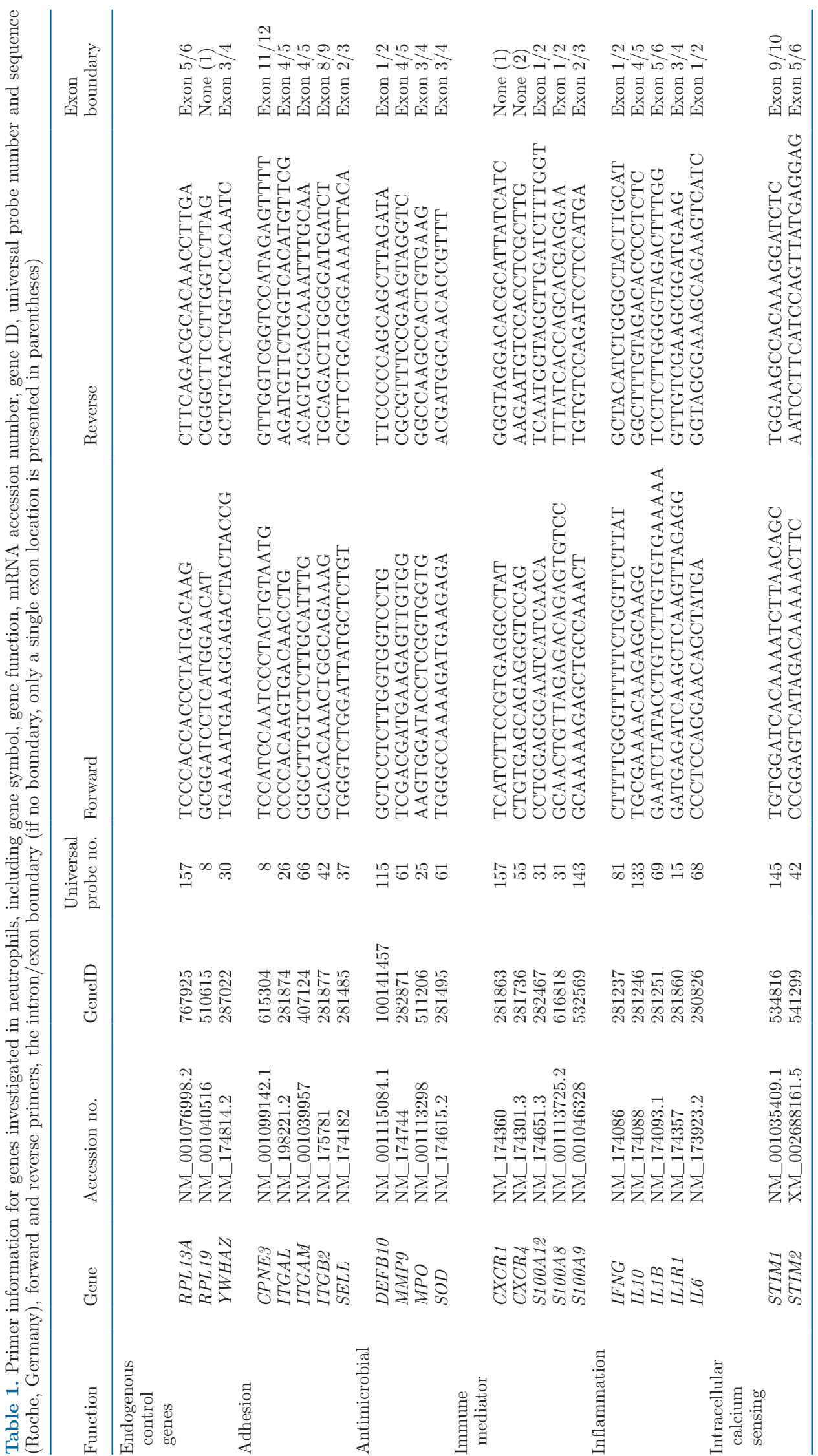


Table 2. Relative gene expression $(\Delta \mathrm{Cp})$ of neutrophils isolated from control cows and cows supplemented with zeolite A prepartum (duration of $17 \mathrm{~d} \pm 3$, mean $\pm \mathrm{SD})^{1}$

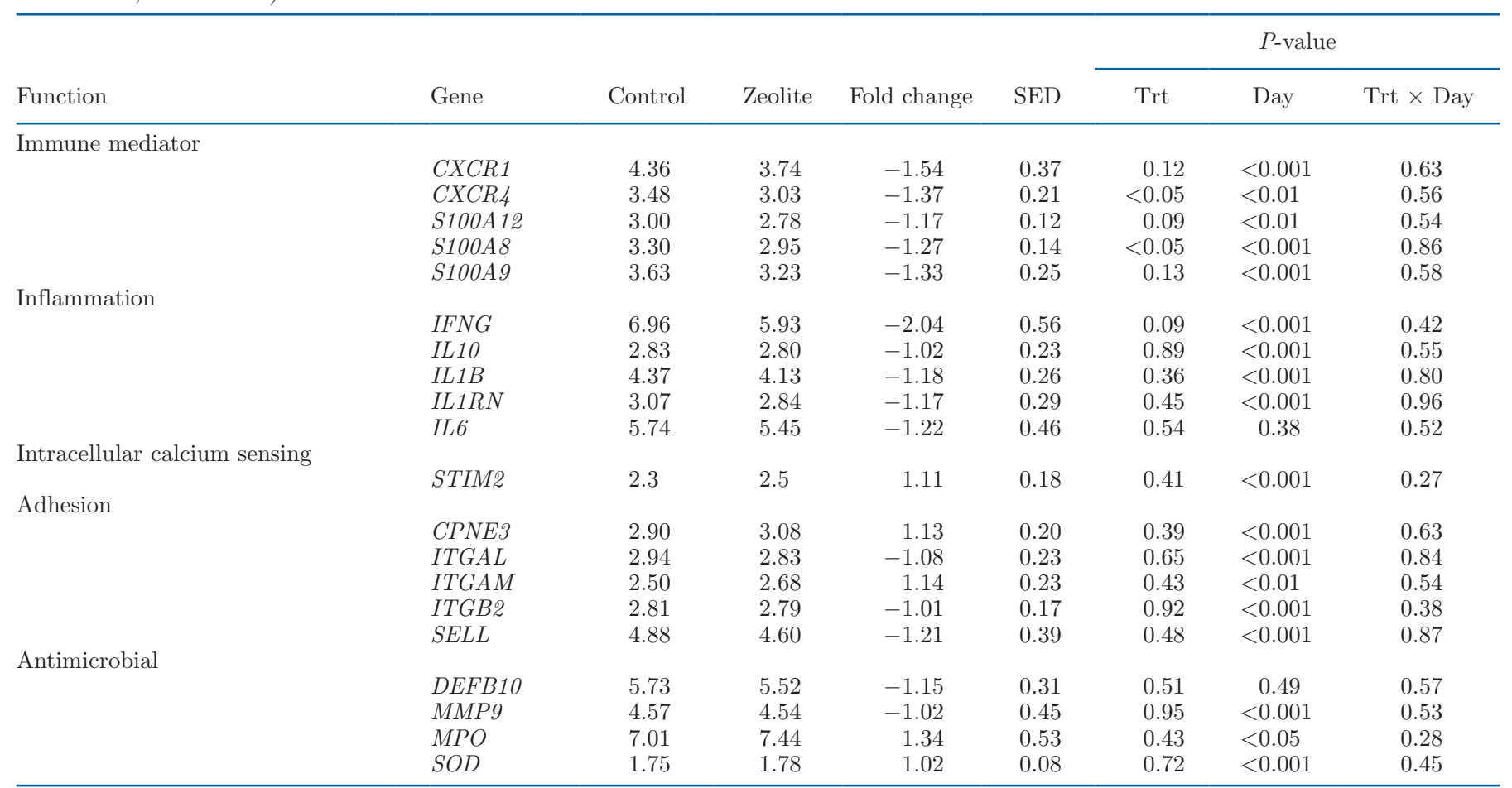

${ }^{1}$ Results are presented as means (LSM) with standard error of the difference (SED). The $P$-values included are for the effect of zeolite treatment (Trt) and time point (Day) and their interaction (Trt $\times$ Day). Relative gene expression of neutrophils isolated from zeolite-treated cows is also expressed as a fold change compared with control cows $(\Delta \Delta \mathrm{Cp})$

\section{Statistics}

A repeated-measures model with a compound symmetry variance-covariance structure was used to analyze the data, considering zeolite treatment, time (day relative to calving: $\mathrm{d}-14,-7,0,1,4,7$, and 28 ), and their interaction as fixed effects. Treatment duration and pretreatment data (where available) were included as covariates and experimental start date was used as a blocking factor. Where necessary, a transformation $\left(\log _{10}\right)$ was applied to match the normality assumption of the modeling. Normalized, $\log _{2}$ transformed data were subjected to proc mixed (SAS/STAT 14.3); $P$ values $\leq 0.05$ were considered statistically significant and $P$-values $\leq 0.13$ were considered a trend toward significance. Results are presented as least squares means (LSM) and SED.

\section{RESULTS AND DISCUSSION}

The addition of zeolite $\mathrm{A}$ into the precalving diet of transition dairy cows had the desired effect of increasing plasma calcium immediately postpartum, consistent with previous studies (Thilsing-Hansen and Jørgensen, 2001; Thilsing et al., 2007; Kerwin et al.,
2019). We hypothesized that the greater availability of calcium would affect gene expression in neutrophils due to its importance in immune cell signaling. Relatively few effects were determined on the expression of genes involved in neutrophil function. Of the 21 genes investigated, 2 genes were significantly $(P<0.05)$ downregulated over the transition period in the zeolite A-treated cows compared with control cows. These 2 genes and another 4 genes that tended to be downregulated included genes that encode proteins involved in the neutrophil inflammatory response and are reliant on calcium availability.

This downregulation of inflammatory genes in neutrophils suggests a dampening of the inflammatory state in zeolite A-treated transition cows. Gene expression of calcium-dependent immune mediators $S 100 A 8(P<$ $0.05)$, S100A9 $(P=0.13)$, and S100A12 $(P=0.09)$ was lower in neutrophils of zeolite A-treated cows compared with neutrophils from control animals (Table 2, Figure 1). Proteins S100A8 and S100A9 form a complex known as calprotectin, which has antimicrobial properties and is important for innate immunity (Foell et al., 2007). In dairy cows, gene expression of $S 100 A 8, S 100 A 9$, and S100A12 (calgranulin A, B, and C) is upregulated in the endometrium of cows with severe negative energy 

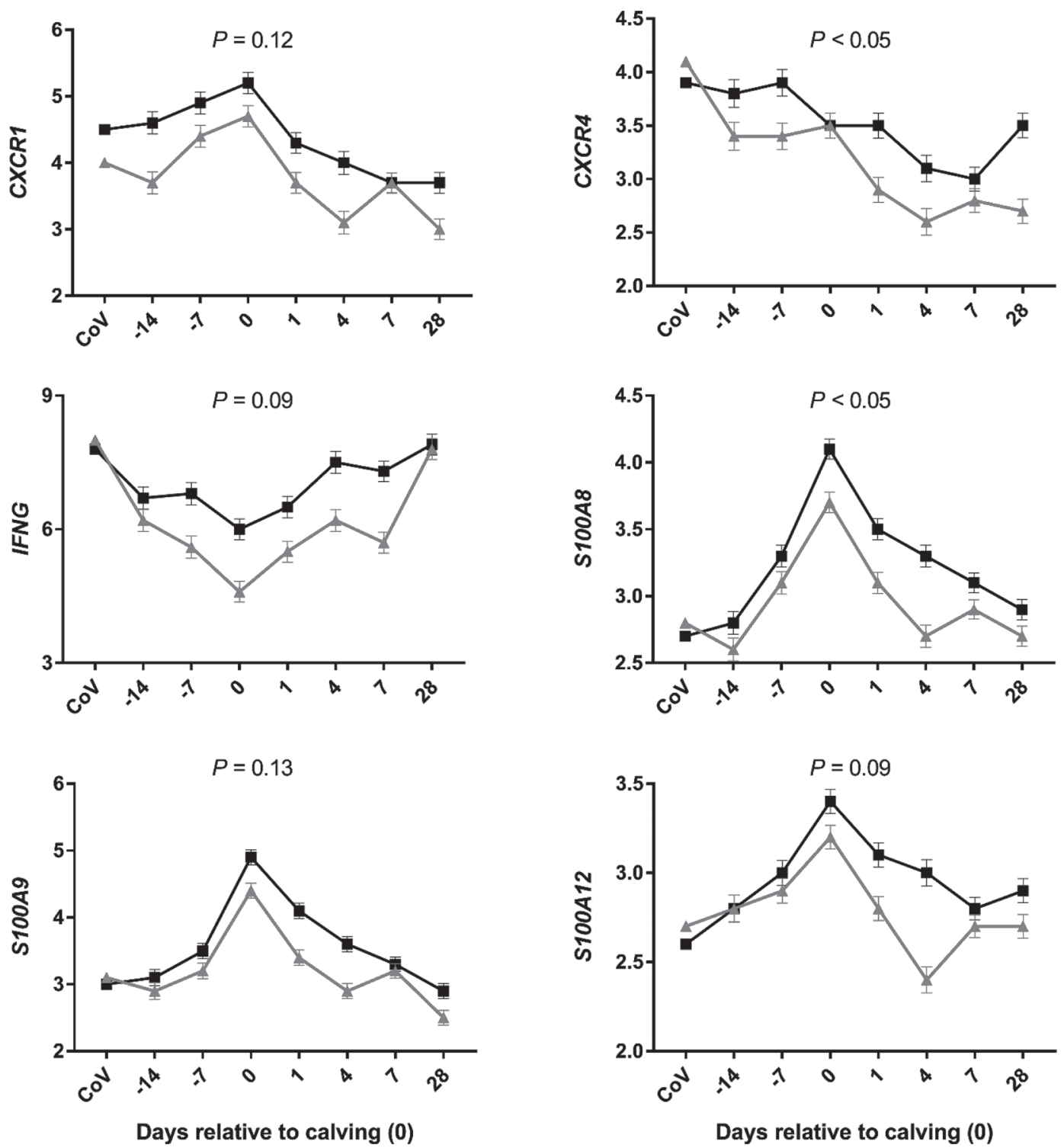

Figure 1. Relative gene expression $(\Delta \mathrm{Cp})$ of neutrophils isolated during the transition period from control cows $($ black squares; $\mathrm{n}=10)$ and cows treated with zeolite A for 2 wk before calving (gray triangles; $\mathrm{n}=10$ ). Values are expressed as LSM \pm standard error of the difference; significance was deemed $P \leq 0.05$. $P$-values displayed are those that tended to be altered by zeolite treatment $(0.05<P<0.13)$; no interactions were found between treatment and time point, $P>0.05$. CoV $=$ covariate $[-19 \pm 3 \mathrm{~d}( \pm \mathrm{SED})]$.

balance and expression is associated with intrauterine infection (Wathes et al., 2009). This finding suggests that upregulation of these genes is indicative of the presence of bacteria and consequent inflammation in certain circumstances. Further support for expression of these proteins as indicators of inflammation is their upregulation by pro-inflammatory cytokines (Mørk et al., 2003). Calgranulin C (encoded by S100A12) acts independently from the calprotectin heterodimer, but these proteins all bind calcium and are involved in neutrophil activation (Vogl et al., 1999). Expression of S100A12 increases in blood during bacterial infection
(Song et al., 2017). Furthermore, S100A12 protein is elevated in inflammatory diseases such as traumatic brain injury, Kawasaki disease, and rheumatoid arthritis (Foell and Roth, 2004; Ye et al., 2004; Feng et al., 2018). Due to the importance of S100 proteins in the inflammatory response and as markers of inflammation, the downregulation of these genes in neutrophils isolated from zeolite-treated animals likely indicates that zeolite A dampens peripartal inflammation.

Zeolite A also downregulated genes important for immune-modulation by neutrophils. Expression of $C X C R 4$ was lower $(P<0.05)$ and expression of 
CXCR1 and the pro-inflammatory cytokine IFNG both tended to be lower $(P=0.12$ and 0.09 , respectively) in neutrophils from zeolite-treated animals compared with control animals (Table 2, Figure 1). Chemokine receptors are important for neutrophil chemotaxis, and chemokine signaling is important for the acute response of neutrophils to migrate during a bacterial infection (Sallusto and Baggiolini, 2008). The CXCR1 protein is the receptor for IL-8, which is an important chemoattractant during inflammation (Mitchell et al., 2003). Gene expression of CXCR1 is downregulated after calving (Seo et al., 2013; Crookenden et al., 2016), and that temporal pattern was also demonstrated in the present study (Figure 1). The expression of CXCR1 did, however, demonstrate a tendency to be lower in neutrophils from zeolite-treated animals over the transition period, relative to control animals (Figure 1). The pathology of several inflammatory diseases involves excessive neutrophil recruitment; therefore, blockade of signaling through CXCR1 has been investigated as a mechanism to reduce neutrophil chemotaxis (Zhao et al., 2007). This line of research suggests that the downregulation of CXCR1 gene expression may be indicative of less neutrophil migration (i.e., chemotaxis) in zeolite-treated animals. Investigation of neutrophil migration in these animals could elucidate this possibility. In cattle, a polymorphism in the $C X C R 1$ gene is associated with impaired neutrophil function, which increases susceptibility to mastitis (Youngerman et al., 2004), further highlighting the importance of CXCR1 in neutrophil function.

The chemokine receptor CXCR4 is a key regulator of neutrophil release from the bone marrow under standard and stress conditions (Eash et al., 2009). As neutrophils age in culture, CXCR4 is dramatically upregulated (Nagase et al., 2002). Martin et al. (2003) demonstrated that high CXCR4 expression is an indication of neutrophil aging in vivo and these cells are rapidly removed from circulation. The presence of CXCR4 on neutrophils during inflammatory conditions is not well known but neutrophils expressing high levels of CXCR4 are present in the joints of patients with inflammatory joint disease (Brühl et al., 2001). These studies suggest that the lower expression of $C X C R 4$ in zeolite-treated animals indicates that the neutrophils are "younger" and these animals may have less peripartal inflammation compared with control animals.

Further indication of a reduced inflammation is downregulation of the gene that encodes pro-inflammatory cytokine interferon gamma $(I F N G)$. Expression of IFNG tended $(P=0.09)$ to be lower in neutrophils from zeolite-treated animals compared with control animals (Table 2). Other evidence to suggest zeolites (either natural or synthetic) act in an anti-inflammatory man- ner is that treatment with a natural zeolite tended to increase production of the anti-inflammatory cytokine IL-10 in endurance-trained athletes (Lamprecht et al., 2015). Consistent with this report are the lower ( $P$ $<0.05$ ) plasma IL-6 concentrations observed here in zeolite-treated animals, especially within the first $24 \mathrm{~h}$ post calving (Table 3). Interleukin-6 is predominantly regarded as a pro-inflammatory cytokine (Scheller et al., 2011) and is capable of delaying neutrophil apoptosis during infection (Colotta et al., 1992), which is consistent with our observation that suggests neutrophils from zeolite-treated animals are younger. Any downstream effects of IL-6 on bovine neutrophils in the present study are unclear, including whether or not the downregulation of immune mediators is positive. However, treatment with zeolite A appears to temporarily downregulate the expression of immune mediators in neutrophils, suggesting an overall decrease in inflammatory status.

We observed a lack of effect of zeolite A on the majority of the genes investigated but a significant day effect for most genes, which suggests that this form of zeolite did not affect several pathways involved in neutrophil function but these pathways are likely altered over the transition period. For example, genes involved in neutrophil attachment were not altered in neutrophils isolated from zeolite A-treated animals (Table 2) and only 2 genes were not altered over time (IL6 and DEFB10). Previous research indicates altered expression of genes in neutrophils over the transition period (Crookenden et al., 2016), which is consistent with observed time effects in the current study. For example, genes involved in neutrophil attachment are altered over the periparturient period (Crookenden et al., 2016), and this alteration is demonstrated again here by a significant effect of day relative to calving $(P$ $<0.01$; Table 2). Neutrophil attachment is a critical step in the neutrophil response to inflammatory signals during pathogen invasion and is superseded by neutrophil migration and exocytosis (Ley et al., 2007). Investigation into the role of cytosolic calcium during neutrophil phagocytosis indicates that transient changes in intracellular $\mathrm{Ca}^{2+}$ are associated with pseudopodia extension and migration, rather than exocytosis and preceding attachment (Suzaki et al., 1997; Eddy et al., 2000; Heo et al., 2015). Therefore, it may be inferred that changes in calcium availability may not alter the processes of attachment and exocytosis, which further supports that the migratory capacity of neutrophils may be affected. As such, the lack of changes in the expression of genes involved in the processes of adhesion and antimicrobial capability in response to zeolite A suggests that the "killing" ability of neutrophils will not be affected. 
Table 3. Effect of treatment with zeolite A (sodium aluminosilicate) on indicators of mineral status, energy status, liver function, and inflammation in control animals $(\mathrm{n}=10)$, or cows supplemented with $500 \mathrm{~g} / \mathrm{cow}$ per day of zeolite A (n=10) for approximately 2 wk before calving (average of $16 \mathrm{~d}$ ); main effects are presented below as means (LSM) with standard error of the difference (SED)

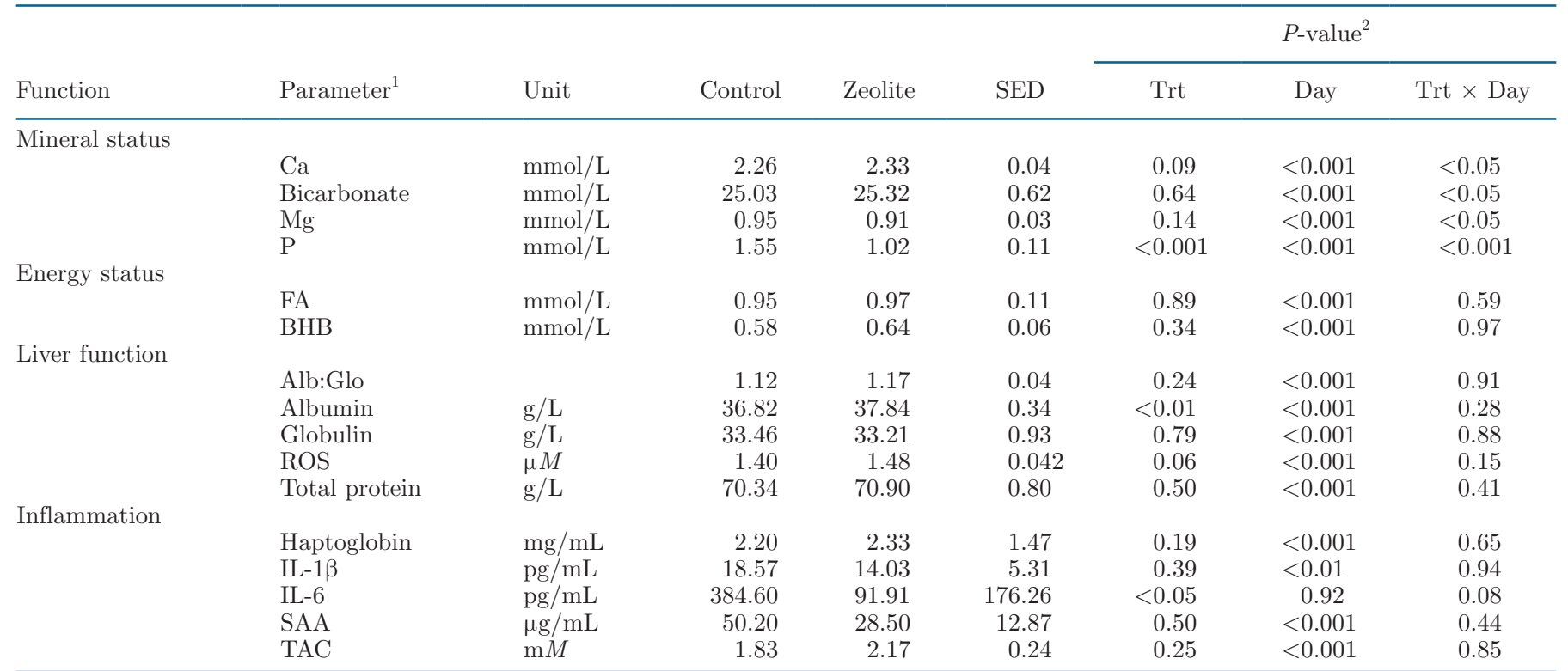

${ }^{1}$ Alb:Glo = albumin to globulin ratio; $\mathrm{FA}=$ nonesterified fatty acids; ROS = reactive oxygen species; TAC = total antioxidant capacity; SAA $=$ serum amyloid $\mathrm{A}$.

${ }^{2}$ The $P$-values included are for the effect of zeolite treatment (Trt) and time point (Day) and their interaction (Trt $\times$ Day).

Prepartum feeding of synthetic zeolite had no effect on neutrophil respiratory burst (Figure $2 ; P>0.10$ ), which suggests it had no effect on this pathway, which neutrophils use to destroy pathogens. However, a significant $(P<0.05)$ change in respiratory burst was observed over time (Figure 2), as should occur over the transition period (Detilleux et al., 1995). We had hypothesized that the increased availability of calcium immediately post calving in zeolite-treated cows would improve this aspect of neutrophil function compared with control cows that experienced subclinical hypocalcemia; however, the improvement did not occur. In support of the lack of treatment effect, neutrophil respiratory burst is not largely or irreversibly affected by an induced hypocalcemia (Kehrli and Goff, 1989), which occurs inherently in control animals immediately post calving with the onset of lactation. Complete removal of lactogenesis, as discussed by Kimura et al. (1999), improved recovery of neutrophil activity after calving, as indicated by myeloperoxidase activity, but did not affect L-selectin (SELL) gene expression (Kimura et al., 1999). Combined, this research suggests that the onset of lactation negatively influences innate immune cell function, but hypocalcemia does not entirely explain peripartal immune dysfunction. It is, therefore, unlikely that the altered availability of macronutrients over the periparturient period detrimentally altered the ability of neutrophils to destroy pathogens. Further functional tests would provide additional insight into the action of zeolite A on neutrophil function.

Zeolite treatment altered the availability of key minerals involved in calcium homeostasis during the tran-

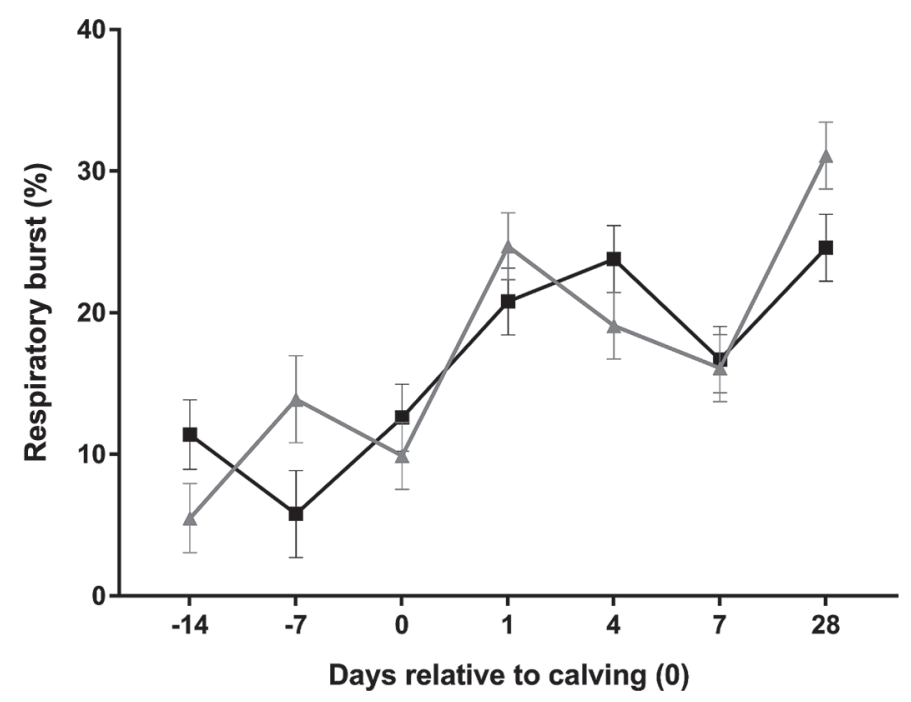

Figure 2. Neutrophil respiratory burst across the transition period in control (black squares) and zeolite A-treated (gray triangles) cows. Values are expressed as LSM \pm standard error of the difference. No significant effect was found for zeolite treatment or an interaction between zeolite treatment and day relative to calving $(P>0.05)$; however, the day effect was significant $(P<0.05)$. 

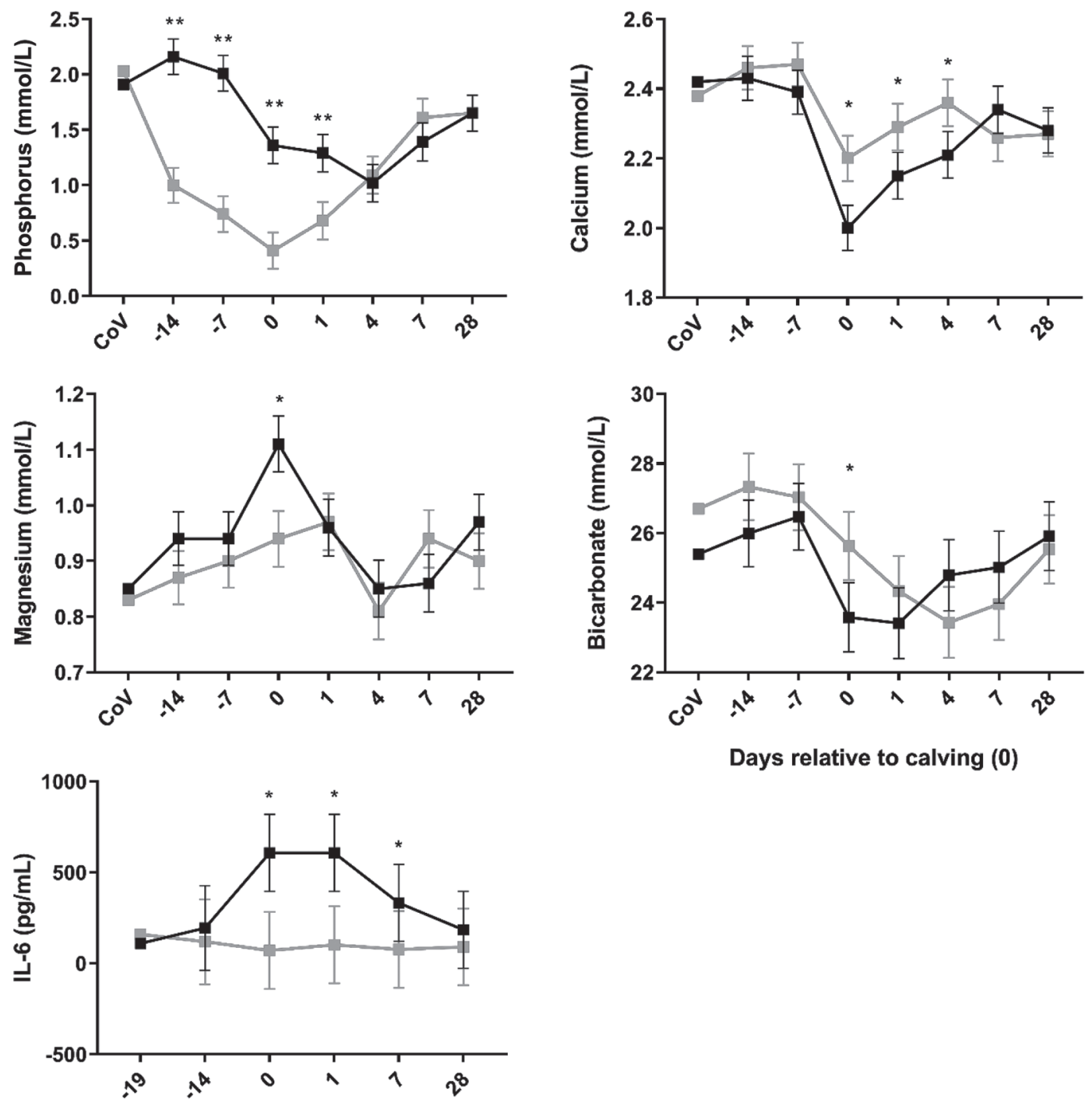

Days relative to calving (0)

Days relative to calving $(0)$

Figure 3. Plasma indicators of mineral status and inflammation across the transition period in control (black squares) and zeolite-treated (gray squares) cows. Minerals and cytokines presented here demonstrated treatment by day interactions $(P<0.10)$. Time points at which the control and zeolite-treated cows were significantly or highly significantly different are indicated by an asterisk $(*)$, and those highly significant $(P<0.01)$ are denoted by 2 asterisks $(* *) . \mathrm{CoV}=$ covariate $[-19 \pm 3 \mathrm{~d}( \pm \mathrm{SED})]$.

sition period (Table 3); plasma phosphorus decreased during the period of zeolite A treatment, magnesium was lower on the day of calving in zeolite-treated cows compared with control cows, and plasma calcium was greater in zeolite-treated cows in the first $4 \mathrm{~d}$ of lactation (Table 3, Figure 3). We hypothesized that the availability of key minerals (i.e., calcium, phosphorus, magnesium) would influence gene expression in neutrophils. However, we observed no time-dependent interactions to suggest that the altered neutrophil gene expression matches altered mineral availability in zeolite A-treated animals. Treatment with zeolite A achieved the desired effect of increasing plasma calcium at the onset of lactation when the demand for calcium suddenly increases. This increased calcium demand results in many cows experiencing clinical and subclinical hypocalcemia (Reinhardt et al., 2011). No clinical cases of milk fever were observed in either control or zeolite-treated cows in the present study. Therefore, treatment with zeolite A reduced the risk of subclinical hypocalcemia (i.e., blood calcium $<2$ to $2.15 \mathrm{mmol} / \mathrm{L}$ ), particularly on the day of calving (average 2 vs. 2.2 $\mathrm{mmol} / \mathrm{L}$ plasma calcium in control compared with zeolite-treated cows, respectively).

Plasma phosphorus was another mineral affected by treatment with zeolite A. Phosphorus was significantly 
greater in control animals compared with zeolitetreated animals during the lead up to calving until 1 $\mathrm{d}$ post calving (Figure 3). Previous research indicates that zeolite $\mathrm{A}$ can bind phosphorus at low $\mathrm{pH}$ in rumen fluid, along with calcium and magnesium (Thilsing et al., 2006; Grabherr et al., 2009). Furthermore, zeolite A has been demonstrated to suppress blood phosphorus precalving in peripartal dry cows and blood magnesium to a lesser extent (Thilsing-Hansen et al., 2002; Kerwin et al., 2019), both of which were also demonstrated in the current study (Figure 3). The positive effect of zeolite on blood calcium concentrations at calving is at least partially dependent upon lower plasma concentrations of phosphorus prepartum as additional prepartum supplementation with phosphorus interferes with the calcium response (Pallesen et al., 2008). Recent research also indicates that hypophosphatemia has a mild negative effect on granulocyte phagocytosis ability in transition dairy cows (Eisenberg et al., 2019). The clinical effects of short-term suppression of plasma phosphate remain unclear. However, chronic hypophosphatemia has detrimental health effects in cows including poor growth/thriftness, reduced appetite, and reduced activity (National Research Council, 2001). It is unlikely the temporary hypophosphatemia induced by zeolite A would induce these ill effects; however, further research should elucidate whether any detrimental health consequences occur when feeding zeolite A.

\section{CONCLUSIONS}

Treatment with zeolite A precalving had few effects on neutrophil gene expression and function, which is limited by ex vivo experimentation. The immune regulators that were downregulated over the transition period suggests a dampening of inflammation in zeolite-treated cows, which may be an indirect result of alterations to mineral availability.

\section{ACKNOWLEDGMENTS}

The authors acknowledge the DairyNZ farm and technical staff for their technical support and assistance with animal handling and sample collection, especially K. Collier, S. Morgan, and B. Sugar. We gratefully acknowledge the statistical analysis and advice of Barbara Kuhn-Sherlock (DairyNZ, Hamilton, New Zealand). We also acknowledge the technical advice of K. Lloyd-Jones, Pirbright Institute, Surrey, for assistance with the neutrophil isolation method; D. Verdon at the University of Auckland for assistance with flow cytometry analysis; and J. Chan at the Ramaciotti Centre for Genomics, UNSW, Sydney, for technical assistance with the Fluidigm gene expression arrays. This work was supported by funding from New Zealand dairy farmers through DairyNZ Inc. (AC1903) and the Ministry of Business, Innovation and Employment (DRCX1302).

\section{REFERENCES}

Brühl, H., K. Wagner, H. Kellner, M. Schattenkirchner, D. Schlöndorff, and M. Mack. 2001. Surface expression of CC- and CXCchemokine receptors on leucocyte subsets in inflammatory joint diseases. Clin. Exp. Immunol. 126:551-559. https://doi.org/10 .1046/j.1365-2249.2001.01679.x.

Colotta, F., F. Re, N. Polentarutti, S. Sozzani, and A. Mantovani 1992. Modulation of granulocyte survival and programmed cell death by cytokines and bacterial products. Blood 80:2012-2020.

Crookenden, M. A., A. Heiser, A. Murray, V. S. R. Dukkipati, J. K. Kay, J. J. Loor, S. Meier, M. D. Mitchell, K. M. Moyes, C. G. Walker, and J. R. Roche. 2016. Parturition in dairy cows temporarily alters the expression of genes in circulating neutrophils. J. Dairy Sci. 99:6470-6483. https://doi.org/10.3168/jds.2015-10877.

Crookenden, M. A., C. G. Walker, B. Kuhn-Sherlock, A. Murray, V. S. R. Dukkipati, A. Heiser, and J. R. Roche. 2017. Technical note: Evaluation of endogenous control gene expression in bovine neutrophils by reverse-transcription quantitative PCR using microfluidics gene expression arrays. J. Dairy Sci. 100:6763-6771. https:// doi.org/10.3168/jds.2016-12460.

Curtis, C. R., H. N. Erb, C. J. Sniffen, R. D. Smith, and D. S. Kronfeld. 1985. Path analysis of dry period nutrition, postpartum metabolic and reproductive disorders, and mastitis in Holstein cows. J. Dairy Sci. 68:2347-2360. https://doi.org/10.3168/jds.S0022 -0302(85)81109-7.

Curtis, C. R., H. N. Erb, C. J. Sniffen, R. D. Smith, P. A. Powers, M. C. Smith, M. E. White, R. B. Hillman, and E. J. Pearson. 1983. Association of parturient hypocalcemia with eight periparturient disorders in Holstein cows. J. Am. Vet. Med. Assoc. 183:559-561.

DeGaris, P. J., and I. J. Lean. 2008. Milk fever in dairy cows: A review of pathophysiology and control principles. Vet. J. 176:58-69. https: //doi.org/10.1016/j.tvjl.2007.12.029.

Detilleux, J. C., M. E. Kehrli, J. R. Stabel, A. E. Freeman, and D. H. Kelley. 1995. Study of immunological dysfunction in periparturient Holstein cattle selected for high and average milk production. Vet. Immunol. Immunopathol. 44:251-267.

Eash, K. J., J. M. Means, D. W. White, and D. C. Link. 2009. CXCR4 is a key regulator of neutrophil release from the bone marrow under basal and stress granulopoiesis conditions. Blood 113:47114719. https://doi.org/10.1182/blood-2008-09-177287.

Eddy, R. J., L. M. Pierini, F. Matsumura, and F. R. Maxfield. 2000. $\mathrm{Ca}^{2+}$-dependent myosin II activation is required for uropod retraction during neutrophil migration. J. Cell Sci. 113:1287-1298.

Eisenberg, S. W. F., L. Ravesloot, A. P. Koets, and W. Grünberg. 2019. Effect of dietary phosphorus deprivation on leukocyte function in transition cows. J. Dairy Sci. 102:1559-1570. https://doi .org $/ 10.3168 /$ jds.2018-15417.

Feng, M. J., W. Bin Ning, W. Wang, Z. H. Lv, X. B. Liu, Y. Zhu, W. Gao, H. Z. Jin, and S. S. Gao. 2018. Serum S100A12 as a prognostic biomarker of severe traumatic brain injury. Clin. Chim. Acta 480:84-91. https://doi.org/10.1016/j.cca.2018.01.044.

Foell, D., and J. Roth. 2004. Proinflammatory S100 proteins in arthritis and autoimmune disease. Arthritis Rheum. 50:3762-3771. https://doi.org/10.1002/art.20631.

Foell, D., H. Wittkowski, T. Vogl, and J. Roth. 2007. S100 proteins expressed in phagocytes: A novel group of damage-associated molecular pattern molecules. J. Leukoc. Biol. 81:28-37. https://doi .org/10.1189/jlb.0306170.

Goff, J. P. 2008. The monitoring, prevention, and treatment of milk fever and subclinical hypocalcemia in dairy cows. Vet. J. 176:50-57. https://doi.org/10.1016/j.tvjl.2007.12.020.

Goff, J. P., and R. L. Horst. 1997. Physiological changes at parturition and their relationship to metabolic disorders. J. Dairy Sci. 80:1260-1268. https://doi.org/10.3168/jds.S0022-0302(97)76055 -7 . 
Grabherr, H., M. Spolders, M. Fürll, and G. Flachowsky. 2009. Effect of several doses of zeolite A on feed intake, energy metabolism and on mineral metabolism in dairy cows around calving. J. Anim. Physiol. Anim. Nutr. (Berl.) 93:221-236. https://doi.org/10.1111/ j.1439-0396.2008.00808.x.

Grafton, G., and L. Thwaite. 2001. Calcium channels in lymphocytes. Immunology 104:119-126. https://doi.org/10.1046/j.0019-2805 .2001.01321.x.

Heiser, A., A. McCarthy, N. Wedlock, S. Meier, J. Kay, C. Walker, M. A. Crookenden, M. D. Mitchell, S. Morgan, K. Watkins, J. J. Loor, and J. R. Roche. 2015. Grazing dairy cows had decreased interferon- $\gamma$, tumor necrosis factor, and interleukin-17, and increased expression of interleukin-10 during the first week after calving. J. Dairy Sci. 98:937-946. https://doi.org/10.3168/ jds.2014-8494.

Heo, D. K., H. M. Lim, J. H. Nam, M. G. Lee, and J. Y. Kim. 2015. Regulation of phagocytosis and cytokine secretion by store-operated calcium entry in primary isolated murine microglia. Cell. Signal. 27:177-186. https://doi.org/10.1016/j.cellsig.2014.11.003.

Horst, R. L., J. P. Goff, and B. J. McCluskey. 2003. Prevalence of subclinical hypocalcemia in US dairy operations. J. Dairy Sci. 86(Suppl. 1):247-248. (Abstr.)

Kehrli, M. E., and J. P. Goff. 1989. Periparturient hypocalcemia in cows: Effects on peripheral blood neutrophil and lymphocyte function. J. Dairy Sci. 72:1188-1196. https://doi.org/10.3168/jds .S0022-0302(89)79223-7.

Kehrli, M. E., B. J. Nonnecke, and J. A. Roth. 1989a. Alterations in bovine neutrophil function during the periparturient period. Am. J. Vet. Res. 50:207-214.

Kehrli, M. E., B. J. Nonnecke, and J. A. Roth. 1989b. Alterations in bovine lymphocyte function during the periparturient period. Am. J. Vet. Res. 50:215-220.

Kerwin, A. L., C. M. Ryan, B. M. Leno, M. Jakobsen, P. Theilgaard, D. M. Barbano, and T. R. Overton. 2019. Effects of feeding synthetic zeolite A during the prepartum period on serum mineral concentration, oxidant status, and performance of multiparous Holstein cows. J. Dairy Sci. 102:5191-5207. https://doi.org/10 $.3168 /$ jds.2019-16272.

Kimura, K., J. P. Goff, and M. E. Kehrli. 1999. Effects of the presence of the mammary gland on expression of neutrophil adhesion molecules and myeloperoxidase activity in periparturient dairy cows. J. Dairy Sci. 82:2385-2392. https://doi.org/10.3168/jds.S0022 -0302(99)75489-5.

Kimura, K., T. A. Reinhardt, and J. P. Goff. 2006. Parturition and hypocalcemia blunts calcium signals in immune cells of dairy cattle. J. Dairy Sci. 89:2588-2595. https://doi.org/10.3168/jds.S0022 -0302(06)72335-9.

Lamprecht, M., S. Bogner, K. Steinbauer, B. Schuetz, J. F. Greilberger, B. Leber, B. Wagner, E. Zinser, T. Petek, S. Wallner-Liebmann, T. Oberwinkler, N. Bachl, and G. Schippinger. 2015. Effects of zeolite supplementation on parameters of intestinal barrier integrity, inflammation, redoxbiology and performance in aerobically trained subjects. J. Int. Soc. Sports Nutr. 12:40. https://doi.org/ 10.1186/s12970-015-0101-z.

Ley, K., C. Laudanna, M. I. Cybulsky, and S. Nourshargh. 2007. Getting to the site of inflammation: The leukocyte adhesion cascade updated. Nat. Rev. Immunol. 7:678-689. https://doi.org/10.1038/ nri2156.

Martin, C., P. C. E. Burdon, G. Bridger, J. C. Gutierrez-Ramos, T. J. Williams, and S. M. Rankin. 2003. Chemokines acting via CXCR2 and CXCR4 control the release of neutrophils from the bone marrow and their return following senescence. Immunity 19:583-593. https://doi.org/10.1016/S1074-7613(03)00263-2.

Martinez, N., C. A. Risco, F. S. Lima, R. S. Bisinotto, L. F. Greco, E. S. Ribeiro, F. Maunsell, K. Galvão, and J. E. P. Santos. 2012. Evaluation of peripartal calcium status, energetic profile, and neutrophil function in dairy cows at low or high risk of developing uterine disease. J. Dairy Sci. 95:7158-7172. https://doi.org/10 $.3168 /$ jds.2012-5812.

Martinez, N., L. D. P. Sinedino, R. S. Bisinotto, E. S. Ribeiro, G. C. Gomes, F. S. Lima, L. F. Greco, C. A. Risco, K. N. Galvão,
D. Taylor-Rodriguez, J. P. Driver, W. W. Thatcher, and J. E. P. Santos. 2014. Effect of induced subclinical hypocalcemia on physiological responses and neutrophil function in dairy cows. J. Dairy Sci. 97:874-887. https://doi.org/10.3168/jds.2013-7408.

Ministry for Primary Industries. 1999. New Zealand Animal Welfare Act. Part 6. Use of animals in research, testing and teaching. Accessed Jan. 20, 2016. http://www.legislation.govt.nz/act/public/ 1999/0142/latest/DLM50499.html?search=sw_096be8ed817c720c _Part+6.

Mitchell, G. B., B. N. Albright, and J. L. Caswell. 2003. Effect of interleukin- 8 and granulocyte colony-stimulating factor on priming and activation of bovine neutrophils. Infect. Immun. 71:1643-1649. https://doi.org/10.1128/iai.71.4.1643-1649.2003.

Mørk, G., H. Schjerven, L. Mangschau, E. Søyland, and P. Brandtzaeg. 2003. Proinflammatory cytokines upregulate expression of calprotectin (L1 protein, MRP-8/MRP-14) in cultured human keratinocytes. Br. J. Dermatol. 149:484-491. https://doi.org/10 .1046/j.1365-2133.2003.05536.x.

Mulligan, F. J., and M. L. Doherty. 2008. Production diseases of the transition cow. Vet. J. 176:3-9. https://doi.org/10.1016/j.tvjl.2007 .12 .018 .

Mumpton, F. A. 1999. La roca magica: Uses of natural zeolites in agriculture and industry. Proc. Natl. Acad. Sci. U. S. A. 96:3463-3470.

Nagase, H., M. Miyamasu, M. Yamaguchi, M. Imanishi, and N. H. Tsuno. 2002. Cytokine-mediated regulation of CXCR4 expression in human neutrophils. J. Leukoc. Biol. 71:711-717.

National Research Council. 2001. Nutrient Requirements of Dairy Cattle. 7th rev. ed. Natl. Acad. Press, Washington, DC.

Neves, R. C., B. M. Leno, K. D. Bach, and J. A. A. McArt. 2018. Epidemiology of subclinical hypocalcemia in early-lactation Holstein dairy cows: The temporal associations of plasma calcium concentration in the first 4 days in milk with disease and milk production. J. Dairy Sci. 101:9321-9331. https://doi.org/10.3168/ jds.2018-14587.

Oetzel, G. R. 2013. Oral calcium supplementation in peripartum dairy cows. Vet. Clin. North Am. Food Anim. Pract. 29:447-455. https: //doi.org/10.1016/j.cvfa.2013.03.006.

Pallesen, A., F. Pallesen, R. J. Jørgensen, and T. Thilsing. 2008. Effect of pre-calving zeolite, magnesium and phosphorus supplementation on periparturient serum mineral concentrations. Vet. J. 175:234-239. https://doi.org/10.1016/j.tvjl.2007.01.007.

Reinhardt, T. A., J. D. Lippolis, B. J. McCluskey, J. P. Goff, and R. L. Horst. 2011. Prevalence of subclinical hypocalcemia in dairy herds. Vet. J. 188:122-124. https://doi.org/10.1016/j.tvjl.2010.03.025.

Roche, J. R. 2003. The incidence and control of hypocalcaemia in pasture-based systems. Acta Vet. Scand. Suppl. 97:141-144.

Roche, J. R., P. G. Dillon, C. R. Stockdale, L. H. Baumgard, and M. J. VanBaale. 2004. Relationships among international body condition scoring systems. J. Dairy Sci. 87:3076-3079. https://doi.org/ 10.3168/jds.S0022-0302(04)73441-4.

Roche, J. R., S. Meier, A. Heiser, M. D. Mitchell, C. G. Walker, M. A. Crookenden, M. Vailati Riboni, J. J. Loor, and J. K. Kay. 2015. Effects of precalving body condition score and prepartum feeding level on production, reproduction, and health parameters in pasture-based transition dairy cows. J. Dairy Sci. 98:7164-7182. https://doi.org/10.3168/jds.2014-9269.

Sallusto, F., and M. Baggiolini. 2008. Chemokines and leukocyte traffic. Nat. Immunol. 9:949-952. https://doi.org/10.1038/ni.f.214.

Scheller, J., A. Chalaris, D. Schmidt-Arras, and S. Rose-John. 2011. The pro- and anti-inflammatory properties of the cytokine interleukin-6. Biochim. Biophys. Acta 1813:878-888. https://doi.org/ 10.1016/j.bbamcr.2011.01.034.

Seo, J., J. S. Osorio, and J. J. Loor. 2013. Purinergic signaling gene network expression in bovine polymorphonuclear neutrophils during the peripartal period. J. Dairy Sci. 96:7675-7683. https://doi .org/10.3168/jds.2013-6952.

Song, F., Y. Qian, X. Peng, X. Li, P. Xing, D. Ye, and H. Lei. 2017. The frontline of immune response in peripheral blood. PLoS One 12:e182294. https://doi.org/10.1371/journal.pone.0182294.

Suzaki, E., H. Kobayashi, Y. Kodama, T. Masujima, and S. Terakawa. 1997. Video-rate dynamics of exocytotic events associated with 
phagocytosis in neutrophils. Cell Motil. Cytoskeleton 38:215-228. https://doi.org/10.1002/(SICI)1097-0169(1997)38:3<215::AIDCM1 > 3.0.CO;2-4.

Thilsing, T., R. J. Jørgensen, and H. D. Poulsen. 2006. In vitro binding capacity of zeolite A to calcium, phosphorus and magnesium in rumen fluid as influenced by changes in $\mathrm{pH}$. J. Vet. Med. Ser. A Physiol. Pathol. Clin. Med. 53:57-64. https://doi.org/10.1111/j .1439-0442.2006.00798.x.

Thilsing, T., T. Larsen, R. J. Jørgensen, and H. Houe. 2007. The effect of dietary calcium and phosphorus supplementation in zeolite A treated dry cows on periparturient calcium and phosphorus homeostasis. J. Vet. Med. Ser. A Physiol. Pathol. Clin. Med. 54:8291. https://doi.org/10.1111/j.1439-0442.2007.00887.x.

Thilsing-Hansen, T., and R. J. Jørgensen. 2001. Hot topic: Prevention of parturient paresis and subclinical hypocalcemia in dairy cows by zeolite A administration in the dry period. J. Dairy Sci. 84:691-693. https://doi.org/10.3168/jds.S0022-0302(01)74523-7.

Thilsing-Hansen, T., R. J. Jørgensen, J. M. D. Enemark, and T. Larsen. 2002. The effect of zeolite A supplementation in the dry period on periparturient calcium, phosphorus, and magnesium homeostasis. J. Dairy Sci. 85:1855-1862. https://doi.org/10.3168/jds.S0022 $-0302(02) 74259-8$.

Vig, M., and J. Kinet. 2009. Calcium signaling in immune cells. Nat. Immunol. 10:21-27. https://doi.org/10.1038/ni.f.220.

Vogl, T., C. Pröpper, M. Hartmann, A. Strey, K. Strupat, C. Van Den Bos, C. Sorg, and J. Roth. 1999. S100A12 is expressed exclusively by granulocytes and acts independently from MRP8 and MRP14. J. Biol. Chem. 274:25291-25296. https://doi.org/10.1074/jbc.274 .36 .25291 .

Wathes, D. C., Z. Cheng, W. Chowdhury, M. A. Fenwick, R. Fitzpatrick, D. G. Morris, J. Patton, and J. J. Murphy. 2009. Nega- tive energy balance alters global gene expression and immune responses in the uterus of postpartum dairy cows. Physiol. Genomics 39:1-13. https://doi.org/10.1152/physiolgenomics.00064.2009.

Ye, F., D. Foell, K. I. Hirono, T. Vogl, C. Rui, X. Yu, S. Watanabe, K. Watanabe, K. I. Uese, I. Hashimoto, J. Roth, F. Ichida, and T. Miyawaki. 2004. Neutrophil-derived S100A12 is profoundly upregulated in the early stage of acute Kawasaki disease. Am. J. Cardiol. 94:840-844. https://doi.org/10.1016/j.amjcard.2004.05.076.

Youngerman, S. M., A. M. Saxton, S. P. Oliver, and G. M. Pighetti 2004. Association of CXCR2 polymorphisms with subclinical and clinical mastitis in dairy cattle. J. Dairy Sci. 87:2442-2448. https: //doi.org/10.3168/jds.S0022-0302(04)73367-6.

Zhao, X., F. Li, J. R. Town, X. Zhang, W. Wang, and J. R. Gordon. 2007. Humanized forms of the CXCR1/CXCR2 antagonist, bovine CXCL8 ${ }_{(3-74)} \mathrm{K} 11 \mathrm{R} / \mathrm{G} 31 \mathrm{P}$, effectively block ELR-CXC chemokine activity and airway endotoxemia pathology. Int. Immunopharmacol. 7:1723-1731. https://doi.org/10.1016/j.intimp.2007.09.008.

\section{ORCIDS}

M. A. Crookenden (1) https://orcid.org/0000-0002-6137-2006

C. V. C. Phyn ๑ https://orcid.org/0000-0002-4912-4069

S. A. Turner (1) https://orcid.org/0000-0003-2654-0673

J. J. Loor (1 https://orcid.org/0000-0003-1586-4365

V. Lopreiato (1) https://orcid.org/0000-0001-6965-7340

C. R. Burke (ㄱ https://orcid.org/0000-0003-3868-8675

A. Heiser ๑ https://orcid.org/0000-0003-0389-6132

J. R. Roche @ https://orcid.org/0000-0002-4165-9253 